\title{
Bayesian estimation of magma supply, storage, and eruption rates using a multiphysical volcano model: Kīlauea Volcano, 2000-2012
}

\author{
Kyle R. Anderson ${ }^{\mathrm{a}, \mathrm{b}, *}$, Michael P. Poland ${ }^{\mathrm{c}}$ \\ ${ }^{a}$ U.S. Geological Survey Hawaiian Volcano Observatory, Hawaii National Park, HI. 96718 USA \\ ${ }^{b}$ Now at: U.S. Geological Survey California Volcano Observatory, Menlo Park, CA. 94025 USA \\ ${ }^{c}$ U.S. Geological Survey Cascades Volcano Observatory, Vancouver, WA. 98683 USA
}

\begin{abstract}
Estimating rates of magma supply to the world's volcanoes remains one of the most fundamental aims of volcanology. Yet, supply rates can be difficult to estimate even at well-monitored volcanoes, in part because observations are noisy and are usually considered independently rather than as part of a holistic system. In this work we demonstrate a technique for probabilistically estimating time-variable rates of magma supply to a volcano through probabilistic constraint on storage and eruption rates. This approach utilizes Bayesian joint inversion of (1) diverse datasets using predictions from a multiphysical volcano model, and (2) independent prior information derived from previous geophysical, geochemical, and geological studies. The solution to the inverse problem takes the form of a probability density function which takes into account uncertainties in observations and prior information, and which we sample using a Markov Chain Monte Carlo algorithm. Applying the technique to Kīlauea Volcano, we develop a model which relates magma flow rates with deformation of the volcano's surface, sulfur dioxide emission rates, lava flow field volumes, and composition of the volcano's basaltic magma. This model accounts for effects and processes mostly neglected in previous supply rate estimates at Kīlauea, including magma compressibility, loss of sulfur to the hydrothermal system, and potential magma storage in the volcano's deep rift zones. We jointly invert data and prior information to estimate rates of supply, storage, and eruption during three recent quasisteady-state periods at the volcano. Results shed new light on the time-variability of magma supply to Kīlauea, which we find to have increased by 35-100\% between 2001 and 2006 (from 0.11-0.17 to 0.18-0.28 $\mathrm{km}^{3} / \mathrm{yr}$ ), before subsequently decreasing to $0.08-0.12 \mathrm{~km}^{3} / \mathrm{yr}$ by 2012 . Changes in supply rate directly impact hazard at the volcano, and were largely responsible for an increase in eruption rate of $60-150 \%$ between 2001 and 2006, and subsequent decline by as much as $60 \%$ by 2012 . We also demonstrate the occurrence of temporal changes in the proportion of Kīlauea's magma supply that is stored versus erupted, with the supply "surge" in 2006 associated with increased accumulation of magma at the summit. Finally, we are able to place some constraints on sulfur concentrations in Kīlauea magma and the scrubbing of sulfur
\end{abstract}


by the volcano's hydrothermal system. Multiphysical, Bayesian constraint on magma flow rates may be used to monitor evolving volcanic hazard not just at Kīlauea but at other volcanoes around the world.

Keywords: Bayes; joint inverse; magma supply rate; eruption rate; Kīlauea; volatile content

\section{Introduction}

The rate at which magma is supplied to a volcano plays a direct and fundamental role in controlling

Multiphysical, physics-based forward models can be used to relate the physics of magma ascent and 7 eruption with a wide range of observations (Anderson \& Segall, 2011). Most simply, conservation of mass

*Corresponding author
Email address: kranderson@usgs.gov (Kyle R. Anderson)

Preprint submitted to Earth and Planetary Science Letters 
values. Posterior PDFs describe our ability to resolve model parameters given the ability of the model to fit observed data, and the independent constraint offered by the prior PDFs. Multiphysical volcano models are well-suited for Bayesian analysis, as they are capable of relating magma physics with a wide range of observations using a relatively simple model parameterization (Anderson \& Segall, 2011, 2013).

Kīlauea Volcano, believed to be fed by an upwelling plume originating within the mantle (Wolfe et al., 2009), is the youngest sub-aerial volcano in the Hawaiian-Emperor chain. Kîlauea (Figure 1) has been in semi-continuous eruption from East Rift Zone (ERZ) vents since 1983 and is one of the world's most comprehensively-monitored volcanoes, offering an outstanding opportunity to estimate time-variable rates of magma supply, storage, and eruption at an extraordinarily active volcano. Observations suggest that the volcano's MSR has waxed and waned during 2000-2012. Following long-term subsidence of the broader summit region and Southwest Rift Zone (SWRZ) during the $1990 \mathrm{~s}$ at up to $\sim 5 \mathrm{~cm} / \mathrm{yr}$ (Figure 2), rapid inflation and high rates of $\mathrm{CO}_{2}$ and $\mathrm{SO}_{2}$ emissions were believed to be associated with a surge in magma supply beginning in 2003 (Poland et al., 2012); summit deflation associated with eruptive activity followed the supply surge, and although inflation resumed in $~ 2010$ it was associated with low rates of ERZ effusion (Poland, 2014) possibly caused by low rates of magma supply. Existing constraints on MSR are largely empirical, however, since the data sets on which these inferences are based are treated independently rather than as a part of a coherent model. Coupling a multiphysical model of the system with diverse observations in a Bayesian inverse procedure - and incorporating recent advances in our conceptual understanding of Kīlauea along with new techniques for measuring the volcano's storage and eruption rates - should yield improved quantitative understanding of the volcano's time-variable magma flow rates.

\section{Model and Observations of K̄̄lauea Volcano}

The basic conceptual model of Kīlauea Volcano was introduced by Eaton \& Murata (1960). Magma supplied to Kīlauea from a source in the mantle rises into summit storage reservoirs, in which it accumulates and from which it may erupt at the surface or move laterally along rift zones, resulting in intrusions and eruptions tens of km from the summit. Although punctuated by dike intrusions and other transient behavior, during eruptions the system often enters a state of quasi-steady magma flux (Swanson, 1972; Tilling et al., 1987). Since the 1983 onset of Kîlauea's currently ongoing ERZ eruption, magma has, for the most part, passed from depth through the summit reservoir and migrated subhorizontally along the ERZ for $\sim 20 \mathrm{~km}$ before erupting as lava flows near the $\mathrm{Pu}^{6} \mathrm{u}^{6} \overline{\mathrm{O}}^{`} \overline{\mathrm{o}}$ eruptive vent. A second eruptive vent opened in 2008 at Kīlauea's summit; this vent exhibits a clear magmatic connection with the summit reservoir and ERZ vent 
(Rowe et al., 2015; Thornber et al., 2015; Patrick et al., 2015) and currently hosts an active lava lake which emits a persistent plume of gas and minor amounts of tephra (Orr et al., 2012).

Decades of ground deformation, seismic, gravity, and petrologic data at Kīlauea have revealed that magma storage at the volcano occurs principally in the summit reservoir system, the shallow rift zones, and possibly within the deeper rifts. Summit storage occurs in a complex of reservoirs at different depths (Baker \& Amelung, 2012; Poland et al., 2014). In the shallow rift zones, magma storage is indicated by ground deformation (Okamura et al., 1988; Baker \& Amelung, 2015), the petrology of erupted products (Thornber et al., 2003, 2015), and direct sampling via drilling (Teplow et al., 2009), but some of these areas appear to be small bodies relict from past intrusive episodes, and here we focus on time periods which avoid geodetic transients in the ERZ suggestive of shallow storage (section S8.1.1). Finally, geodetic evidence of quasicontinuous seaward-motion of Kīlauea's south flank suggests that Kīlauea's deep rift system is opening by tens of $\mathrm{cm} / \mathrm{yr}$, which could accommodate a significant fraction of the magma supplied to the volcano (Owen et al., 2000; Cayol et al., 2000). South flank motion is complex, however (e.g., Denlinger \& Morgan (2014)), and evidence that deep rift opening is associated with magma storage is contradictory (Poland et al., 2014); it thus remains unknown just how much, if any, magma is stored in this region of the volcano.

With this general framework in mind, we develop a model of Kīlauea Volcano (Figure 1) in which the mass rate of magma supplied to the volcano is balanced by the mass rates of magma stored in the subsurface plus that which is erupted at the surface (e.g., Gonnermann et al. (2012)). Mass flow rates are related to volumetric flow rates using magma densities throughout the system, and volume flow rates are related to observations of ground deformation, accounting for compressibility of the magma. Magmatic sulfur concentrations are used to relate eruption rate with observed $\mathrm{SO}_{2}$ emissions. We model the system during three quasi-steady-state time periods which allow us to examine possible months- to years-long changes in magma fluxes at the volcano (Table 1 and Figure 2): (1) $t_{1}$, spanning 2000-2001, (2) $t_{2}$, from Dec. 2005 to Dec. 2006, and (3) $t_{3}$, from Oct. 2011 to May 2012. Start and end dates are chosen based on the availability of data and prior information necessary to constrain storage and eruption rates (eruption rates in particular are not well known during many time periods at Kīlauea).

Denoting mass flow rates of non-volatile bulk magma (melt and crystals) by $Q$,

$$
Q_{i}=Q_{s}+Q_{r}+Q_{o}
$$

(c.f. Gonnermann et al. (2012)) where subscripts represent $[i]$ nflow (supply), [s] ummit storage, $[r]$ ift storage, and $[o]$ utflow (eruption). (Symbols are defined in Table 2.) In this sign convention, positive $Q$ represent flow of magma from Kīlauea's deep supply into storage reservoirs and towards the ERZ for eruption; $Q_{i} \geq 0$, 
$Q_{r} \geq 0$ (because deformation indicates persistent rift opening), and $Q_{o} \geq 0$ always, but $Q_{s}$ may be positive or negative according to whether or not magma accumulates in or is withdrawn from summit reservoirs. This mass balance holds regardless of whether or not all of Kîlauea's magma supply passes through the summit before entering the rifts (an ongoing source of debate; see Poland et al. (2014)).

To relate mass flow rates $Q$ with volume flow rates $q$ we use

$$
q_{j}=Q_{j} / \rho_{j} \quad ; j=i, s, r, o
$$

where the magma's bulk density $\rho$ depends on the density of the basaltic melt and crystals and varies as magma moves through the volcano's plumbing system. We derive prior distributions for $\rho_{i}, \rho_{s}, \rho_{r}$, and $\rho_{o}$ from previous geophysical, geochemical, and geological studies (prior distributions used in this study are mathematically defined in the Supplementary Material and shown in Figure 3). These distributions account for storage of magma at different density throughout the system; for instance, magma in the summit reservoir system is probably mostly melt, while in the deep rift it may take the form of a dense ultrabasic cumulate mush (Ryan, 1988).

\subsection{Magma Storage}

Addition or subtraction of magma from storage reservoirs will generally alter reservoir pressure and, because magma is compressible, change the density of the stored magma. As a result, the rate of volumetric magma storage $q$ in a reservoir does not in general equal the rate of volume change $V^{\prime}$ (prime terms denote rates of change) of the reservoir itself in the crust, to which geodetic data are sensitive (e.g., Johnson et al. (2000)). For Kīlauea's summit, we relate these using

$$
V_{s}^{\prime}=q_{s} /\left(1+R_{s}\right),
$$

(section S1.2), where $R_{s}$ is the ratio of magma compressibility to reservoir compressibility (section S4.2). In the case of large $R_{s}$ (e.g., for a very bubbly magma in a spherical reservoir), a significant disparity will be introduced between the reservoir volume change estimated from geodetic data and the actual volume of magma added or subtracted (Johnson et al., 2000; Rivalta \& Segall, 2008). $R_{s}$ may be obtained by computing magma and reservoir compressibilities directly, but such calculations are strongly dependent on host rock strength, reservoir shape, and especially exsolved bubble fraction - none of which are well known. We therefore leave $R_{s}$ as a free parameter which we constrain using a prior distribution derived from theoretical modeling and observations of past eruptions (section S4.2).

For simplicity, we directly constrain $V_{s}^{\prime}$ during $t_{1}$ (denoted by $V_{s \mid t_{1}}^{\prime}$ ) using a prior distribution derived from the results of a previous GPS and leveling study during 1996-2002 (section S4.4; Cervelli \& Miklius 
(2003)). For other periods we compute ground deformation at the summit from $V_{s}^{\prime}$ and compare directly to data. Because our goal is only to place first-order constraint on rates of magma storage and not to carefully constrain the location and geometry of storage reservoirs, we treat the summit storage system as a single reservoir and compute ground deformation using simple elastic models, in which rates of ground deformation $\mathbf{u}_{s}^{\prime}$ in three dimensions are directly proportional to $V_{s}^{\prime}$ and functions $f$ of reservoir location $\xi$, observation coordinates $\mathbf{x}$, and additional parameters $\mathbf{g}$ governing reservoir shape and host rock properties:

$$
\mathbf{u}_{s}^{\prime}(\xi, \mathbf{x}, \mathbf{g})=V_{s}^{\prime} f(\xi, \mathbf{x}, \mathbf{g}) .
$$

Because of temporal changes in the style of magma storage in Kīlauea's summit, we use different $f$ for different time periods. For $t_{2}$, following Myer et al. (2008), Baker \& Amelung (2012), and Poland et al. (2012), we use a model of an opening rectangular sill (Okada, 1985) beneath the summit and upper SWRZ, while for $t_{3}$ we use a model of a spherical magma reservoir (Mogi, 1958). In the first case $\mathbf{g}$ is a function of the sill's length, width, and strike, while in the second it is only a function of Poisson's ratio $\nu$. Model predictions in $t_{2}$ are compared to a single ascending-mode ENVISAT radar interferogram spanning 12 Dec. 2005 to 31 Dec. 2006, while for $t_{3}$ we use one ascending-mode and one descending-mode COSMO-SkyMed interferogram spanning 21 Oct. 2011 to 16 May 2012 and 20 Oct. 2011 to 15 May 2012, respectively. InSAR data processing is described in section S3.1.

For storage in Kīlauea's deep rift, we argue that $R$ must be negligible (section S4.3), so

$$
V_{r}^{\prime} k_{r}=q_{r} \quad ; \quad 0 \leq k_{r} \leq 1
$$

where $k_{r}$ is a scaling factor that accounts for the unclear relation between deep rift opening and magma storage. Varying $k_{r}$ between 0 and 1 allows the model to simulate the range of possible deep rift storage (DRS) conditions, from all deep rift opening being associated with magma accumulation $\left(k_{r}=1\right)$ to no magma storage in the deep rift zones $\left(k_{r}=0\right)$. Although $V_{r}$ may be modeled directly using deformation data, this approach is complex and computationally expensive when used in an inverse procedure. Because DRS has occurred at a near-constant rate during the time periods over which our model is applied (Poland et al., 2014), and observations constraining $k_{r}$ are ambiguous (section S4.5), we apply a prior distribution on the product $V_{r}^{\prime} k_{r}$ that is uniform between 0 (no DRS) and an upper limit on $V_{r}^{\prime}$ obtained from previous inversions of south-flank deformation data $\left(\sim 0.045 \mathrm{~km}^{3} / \mathrm{yr}\right.$; section $\left.\mathrm{S} 4.5\right)$. 


\subsection{Magma Output}

Only recently have direct, high-precision estimates of Kīlauea's time-averaged lava eruption rates become available through the TanDEM-X radar mission (Poland, 2014). To constrain eruption rate in $t_{3}$ we use a TanDEM-X estimate of bulk eruption rate for 15 Sept 2011 through 25 May 2012 (ignoring a brief period of ocean entry), converted to volume flow rate using equation (2). To be conservative, for the TanDEM-X data we use a relative measurement uncertainty of $2 \%$, although actual measurement errors are likely much smaller.

TanDEM-X data are unavailable for $t_{1}$ and $t_{2}$. For these periods we use the rate of $\mathrm{SO}_{2}$ emissions from the eruption site as a proxy for eruption rate (Sutton et al., 2003), accounting for minor summit emissions (prior to the 2008 onset of Killauea's summit eruption, more than $90 \%$ of $\mathrm{SO}_{2}$ emissions were recorded from the ERZ, where magma first neared the surface). We use $\mathrm{SO}_{2}$ emissions data from Elias \& Sutton (2007); see section S3.2. We do not use $\mathrm{SO}_{2}$ emissions data after 2008, since the opening of the summit vent at that time has complicated interpretation of traditional spectrographic measurements (Elias \& Sutton, 2012). Sulfur dioxide emissions at the summit and ERZ are related to magma and sulfur flow rates using

$$
\begin{aligned}
& E_{e s}^{S O_{2}}=\left(f^{S O 2} / f^{S}\right) Q_{e s}^{S} \\
& E_{e e}^{S O_{2}}=\left(f^{S O 2} / f^{S}\right) Q_{o} \chi_{e e}^{S},
\end{aligned}
$$

respectively, where $f^{S O 2}$ and $f^{S}$ are molecular weights of sulfur dioxide and sulfur, respectively, $f^{S O 2} / f^{S} \approx$ 2 , and

$$
Q_{e s}^{S}=\left(Q_{o}+Q_{r}\right)\left(\chi_{i}^{S}-\chi_{o}^{S}-\chi_{e e}^{S}-\chi_{s b}^{S}\right)
$$

from conservation of sulfur throughout the system (section S1.1). Here, $Q_{e s}^{S}$ represents the mass rate of sulfur emitted to the atmosphere at the summit, and $\chi^{S}$ terms are sulfur concentrations. This equation is derived under the assumption that DRS magma passes through the summit (section S1.1), but allowing DRS magma to bypass the summit little affects the sulfur mass balance because summit $\mathrm{SO}_{2}$ emissions are minor during modeled time periods.

From equation (7), constraint on the mass fraction of sulfur emitted from erupted ERZ lavas, $\chi_{e e}^{S}$, is required in order to relate $\mathrm{SO}_{2}$ emissions with eruption rate. $\chi_{e e}^{S}$ has been previously estimated utilizing observed carbon/sulfur ratios in ERZ gas emissions together with a modeled concentration of $\mathrm{CO}_{2}$ in the ERZ (Sutton et al., 2003) (see section S4.9), but the latter may not be well known. Instead, we utilize equations (6) and (8) together with observed summit $\mathrm{SO}_{2}$ emissions and constraint on concentrations of sulfur $\chi^{S}$ at 
various points in the system. Sulfur concentration $\chi_{i}^{S}$ in the primary melt is constrained using the results of previous studies of melt inclusions and submarine-erupted basalts (which are quenched under pressure prior to significant degassing) (section S4.7). Similarly, we use geochemical observations to constrain the small amount of sulfur that remains in solidified basalts $\chi_{o}^{S}$ (section S4.8). We are unable to constrain $\chi_{s b}^{S}$, the loss of sulfur to ground or surface water ("scrubbing") before emission into the atmosphere (although it is unlikely that $\chi_{s b}^{S}$ is significant at $\mathrm{Pu}^{\prime} u$ ' $\overline{\mathrm{O}}^{\prime} \overline{\mathrm{o}}$, the importance of scrubbing at Kîlauea's summit is not well known; section S2). We therefore use previous estimates of $Q_{o}$ during $t_{1}$ (see section S4.6) obtained from very-low-frequency (VLF) electromagnetic estimates of flow through lava tubes, geologic mapping, and summit ground tilt (Sutton et al., 2003; Heliker \& Mattox, 2003) to estimate $\chi_{e e}^{S}$ and $\chi_{s b}^{S}$ during $t_{1}$. Assuming that these concentrations did not change significantly between $t_{1}$ and $t_{2}$, eruption rate in $t_{2}$ may be estimated utilizing only $\mathrm{SO}_{2}$ emissions data (equation (7)).

\section{Inverse}

We hypothesize that observed data $\mathbf{d}$ can be described using $\mathbf{d}=\mathbf{G}(\mathbf{m})+\epsilon$, where $\mathbf{G}$ is a nonlinear function (the forward model) of the model vector $\mathbf{m}$, and errors $\epsilon$ follow a Gaussian distribution with mean $\mathbf{0}$ and covariance $\Sigma$. We manually weight $\Sigma$ for gas data such that the variation in model predictions reasonably matches variation (scatter) in the data.

We simultaneously invert the data from $t_{1}, t_{2}$, and $t_{3}$, allowing some parameters - such as magma supply, storage and eruption rates - to vary between time periods but assuming that others remain constant (including $V_{r}^{\prime} k_{r}$ and $\chi^{S}$, as suggested by the near-constant rate of south flank deformation and the lack of temporal trends in petrologic data and following Greenland et al. (1985) and Poland et al. (2012)). Under these assumptions, the model vector is given by

$$
\mathbf{m}=\left[\mathbf{Q}_{\mathbf{o}}, \mathbf{V}_{\mathbf{s}}^{\prime}, V_{r}^{\prime} k_{r}, R_{s}, \chi^{S}, \chi_{s b}^{S}, \chi_{e e}^{S}, \chi_{o}^{S}, \rho_{j}, \xi, \mathbf{g}\right]^{\mathrm{T}},
$$

where $j=s, r, o$ (we do not invert for $\rho_{i}$ directly but use its distribution in postprocessing to compute $q_{i}$ from $\left.Q_{i}\right), \mathbf{Q}_{\mathbf{o}}=\left[Q_{o \mid t_{1}}, Q_{o \mid t_{2}}, Q_{o \mid t_{3}}\right], \mathbf{V}_{\mathbf{s}}^{\prime}=\left[V_{s \mid t_{1}}^{\prime}, V_{s \mid t_{2}}^{\prime}, V_{s \mid t_{3}}^{\prime}\right], \xi=\left[\xi_{\mid t_{2}}, \xi_{\mid t_{3}}\right]$, and $\mathbf{g}=\left[\mathbf{g}_{\mid t_{2}}, \nu\right]$. The deformation source position vector $\xi$ contains east, north, and depth parameters, and $\mathbf{g}_{\mid t_{2}}$ contains sill length, width, and strike. Note that we postprocess to obtain MSR and certain other distributions of interest.

We follow the general inverse approach of Anderson \& Segall (2013) and use Bayes' Theorem to compute the posterior PDF using

$$
P(\mathbf{m} \mid \mathbf{d}) \propto P(\mathbf{d} \mid \mathbf{m}) P(\mathbf{m}) .
$$


The likelihood function $P(\mathbf{d} \mid \mathbf{m})$ is a measure of the fit of model predictions to observed data, accounting for data uncertainties, while $P(\mathbf{m})$ is the prior probability function. Thus, model parameters are constrained by the fit of model predictions to the data and by prior probability distributions. To sample (evaluate) the posterior PDF, we perform a standard Markov Chain Monte Carlo simulation with the Metropolis algorithm (e.g., Mosegaard \& Tarantola (1995)), which is allowed to run until 48 independent Markov chains converge to similar distributions, which we combine to produce the final PDF (section S6).

We emphasize that our goal is not to find a single best-fitting model but rather to explore the full range of model parameters consistent with observations. To ensure that uncertainties are fully considered, we let all 25 model parameters vary in the inverse procedure. We do not expect the inverse to offer improved constraint on many of these parameters, such as Poisson's ratio - however, by allowing these parameters to vary freely over their a priori range, we ensure that uncertainties are propagated fully into estimates of magma supply, storage, and eruption rates. We consider this a key element of the Bayesian inverse approach utilized here.

\section{Results}

Prior and posterior PDFs for estimated model parameters are shown in Figure 3. It is important to remember that posterior PDFs include uncertainties in data and prior information, but cannot account for the extent to which the model $\mathbf{G}$ misrepresents reality (so-called model error). Although we have attempted to reduce model error by constraining certain model parameters (such as $R_{s}$ ) using rough prior constraints rather than computing them directly, uncertainties below should be considered minimums. Possible sources of remaining model error in this study include unmodeled magma storage away from the summit, the influence of secular motion on deformation data, viscoelastic behavior of summit magma reservoirs, the simple idealized deformation sources we use, the storage of magma in void space in the summit, and the assumption of a direct relationship between magma flow rate and gas emission rates. Some of these uncertainties are discussed more fully in section S8.

The model is able to fit observations for all time periods to within uncertainties (Figure 4). Model predictions fall within the scatter in gas emissions data and explain the majority of InSAR-observed deformation.

In the following sections, the notation $a-b$ is generally used to represent posterior PDFs, where $a$ and $b$ indicate lower and upper $68 \%$ confidence bounds, respectively. Median values and $95 \%$ confidence bounds are provided in Table 3. We emphasize, however, the importance of considering the full shape of the posterior PDFs presented in the figures. 


\subsection{Eruption Rates and Sulfur Concentrations}

Estimated eruption rates are given in Table 3 and shown in Figure 5 . Eruption rate during $t_{1}$ is constrained by its prior PDF, and in $t_{2}$ by $\mathrm{SO}_{2}$ emissions data. (In section $\mathrm{S} 5$ we investigate placing prior constraint on $\chi_{e e}^{S}$ rather than on eruption rate in $t_{1}$ as described in section 2.2 ; we find that results are similar, but parameter estimates are less well resolved.) Eruption rate during $t_{3}$ is very tightly resolved by TanDEM-X data, and is consistent with other evidence for low rates during 2010-2013 (Poland, 2014; Orr et al., 2015). Relative changes in eruption rates between time periods are discussed in section 5.2.

Results place some constraint on sulfur concentrations in Kīlauea's magma. Posterior PDFs for $\chi^{S}$ and $\chi_{o}^{S}$ are not improved over prior PDFs, but we are able to constrain $\chi_{e s}^{S}, \chi_{e e}^{S}$ and $\chi_{s b}^{S}$ (during $t_{1}$ and $t_{2}$ ). We estimate $\chi_{e e}^{S}=0.06-0.10 \mathrm{wt} \%$, in agreement with Sutton et al. (2003), who used $\chi_{e e}^{S}=0.075$ wt\% with $\mathrm{SO}_{2}$ emissions to estimate eruption rates consistent with our prior constraint. Although we are able to fit observations without any scrubbing of sulfur by Kīlauea's hydrothermal system, neither can we rule out high rates of scrubbing; of $12.1-19.2 \mathrm{~kg} / \mathrm{s}$ and $19.7-31.7 \mathrm{~kg} / \mathrm{s}$ of sulfur that entered Kīlauea's magma system in $t_{1}$ and $t_{2}$, respectively, as much as $7.6 \mathrm{~kg} / \mathrm{s}$ and $10.7 \mathrm{~kg} / \mathrm{s}(43 \%$ and $36 \%$, at $68 \%$ confidence) may have been scrubbed by the hydrothermal system prior to detection, respectively.

Such high rates seem inconsistent with qualitative arguments against significant scrubbing at Kīlauea, but are difficult to rule out a priori. We perform inversions in which we allow for no loss of sulfur to Kīlauea's hydrothermal system; unsurprisingly, results indicate higher erupted sulfur concentrations $\chi_{e e}^{S}$ in the ERZ (closer to 0.1 wt\%, which is higher than estimated in Sutton et al. (2003)), in turn yielding slightly lower eruption rates (at the lower end of the prior range for $Q_{o \mid t_{1}}$ ). The influence of scrubbing on estimated MSR is discussed briefly in section 4.3 .

\subsection{Magma Storage Rates}

Volume change rate $V^{\prime}$ of Kīlauea's active summit magma reservoir during $t_{1}$ is constrained here by its prior PDF (Figure 3; section S4.4). During $t_{2}$, InSAR data (Figure 4) suggest a long, thin, southweststriking sill at a depth of $4.5-4.9 \mathrm{~km}$. We estimate a volume change rate of $0.45-0.48 \mathrm{~m}^{3} / \mathrm{s}$, in general agreement with a variety of previous studies across different time periods in 2006 yielding anywhere from 0.25 to $2.8 \mathrm{~m}^{3} / \mathrm{s}$ (with variation due in part to variations in the rate and location of inflation that occurred during 2006) (Myer et al., 2008; Poland et al., 2012; Baker \& Amelung, 2012). During $t_{3}$, InSAR data suggest a spherical reservoir beneath the northeast margin of Halema'uma'u Crater at 1.9-2.5 km depth with a volume change rate of $0.04-0.05 \mathrm{~m}^{3} / \mathrm{s}$, roughly an order of magnitude lower than in 2006 (Figure 5 ). 
Although these models adequately fit the InSAR data (Figure 4), we emphasize again the simplicity of our deformation modeling, which is designed to resolve first-order rates of reservoir volume change rather than provide detailed constraint on storage locations or geometries.

Reservoir volume change rates $V^{\prime}$ yield estimates of magma storage rates to within uncertainties on the magma compressibility ratio $R_{s}$. We estimate low rates of magma withdrawal during $t_{1}$ at $-0.16--0.02 \mathrm{~m}^{3} / \mathrm{s}$, storage during $t_{2}$ at $0.73-1.87 \mathrm{~m}^{3} / \mathrm{s}$, and storage during $t_{3}$ at $0.07-0.19 \mathrm{~m}^{3} / \mathrm{s}$ (Figure 5 ). Thus, up to several times more magma may have been stored in the summit than geodetic constraint on $V_{s}^{\prime}$ might indicate (and highlighting the importance of future work to constrain compressibility).

Results here do not improve constraint on DRS above that already offered by the prior PDF. However, it is clear that DRS $\left(k_{r}>0\right)$ is not necessary to fit the data. In the next section we investigate the influence of uncertainty in DRS on estimated MSR.

\subsection{Magma Supply Rates}

We estimate magma supply rates in $t_{1}, t_{2}$, and $t_{3}$ of $0.11-0.17 \mathrm{~km}^{3} / \mathrm{yr}, 0.18-0.28 \mathrm{~km}^{3} / \mathrm{yr}$, and $0.08-$ $0.12 \mathrm{~km}^{3} / \mathrm{yr}$, respectively (Figure 5; mass flow rates in tons/day and volume flow rates in $\mathrm{m}^{3} / \mathrm{s}$ are given in Table 3). These values can be interpreted as the rate of magma supply from the mantle source region through the lithosphere to Kīlauea Volcano, exclusive of supply to other volcanoes such as Mauna Loa (Miklius \& Cervelli, 2003; Gonnermann et al., 2012) or storage in deep, geodetically-invisible storage reservoirs (Gonnermann et al., 2012).

Over millions of years, average supply rates from the Hawaiian hot spot to all of Hawai'i’s active volcanoes has probably averaged $0.05-0.2 \mathrm{~km}^{3} / \mathrm{yr}$, possibly increasing over the last $30 \mathrm{Ma}$ (Robinson \& Eakins, 2006; Poland et al., 2014). Contemporary estimates of MSR to Kīlauea range from $<0.05 \mathrm{~km}^{3} / \mathrm{yr}$ to nearly $0.20 \mathrm{~km}^{3} / \mathrm{yr}$ during various time intervals between the $1950 \mathrm{~s}$ and the onset of the ongoing $\mathrm{Pu}^{6} \mathrm{u}{ }^{6} \overline{\mathrm{O}}^{6} \overline{\mathrm{O}}$ eruption (e.g., Swanson (1972); Dzurisin et al. (1980); Dvorak \& Dzurisin (1993); Cayol et al. (2000); Wright \& Klein (2008)), and from 0.08 to $0.18 \mathrm{~km}^{3} / \mathrm{yr}$ during various parts of 1983-2002 (e.g., Wolfe et al. (1987); Denlinger (1997); Cayol et al. (2000); Heliker \& Mattox (2003); Sutton et al. (2003)). Most recently, Poland et al. (2012) estimated at least $0.2 \mathrm{~km}^{3} / \mathrm{yr}$ and Wright \& Klein $(2014) \sim 0.4 \mathrm{~km}^{3} / \mathrm{yr}$ for the 2006 supply surge. Interested readers are referred to reviews in Poland et al. (2014) and Klein and Wright (in review).

Our posterior PDFs fall within the wide range of these contemporary estimates, but should improve upon them by including additional constraints, propagation of uncertainties, and important factors mostly neglected in previous work. No previous studies have accounted for magma compressibility, and of the handful that have attempted to include DRS, all have fixed it to the volume determined from models of 
deep rift opening under the assumption that all rift opening is produced by magma storage (Cayol et al., 2000; Wright \& Klein, 2014). Here, we argue that DRS cannot be constrained a priori any better than $0-\sim 0.045 \mathrm{~km}^{3} / \mathrm{yr}$ (Figure 3) on the basis of current understanding of Kinlauea (section S4.5), so we allow it to vary freely over this range such that our posterior PDFs encompass both end-member possibilities as well as all intermediate values. Failure to account for uncertainty in DRS could greatly bias estimated MSR; for instance, under the assumption of no DRS $\left(k_{r}=0\right)$, we estimate a rate of $0.088-0.13 \mathrm{~km}^{3} / \mathrm{yr}$ in $t_{1}$, while with $0.045 \mathrm{~km}^{3} / \mathrm{yr}$ of DRS, estimated MSR increases to $0.13-0.18 \mathrm{~km}^{3} / \mathrm{yr}$ (Figure S1). Thus, DRS represents one of the most important sources of uncertainty in any mass-balance based estimate of MSR (section S8.2), and explains in part why our estimates are generally lower than those in Cayol et al. (2000) (0.14-0.18 $\mathrm{km}^{3} / \mathrm{yr}$ for 1983-1991) and Wright \& Klein (2014) $\left(\sim 0.2 \mathrm{~km}^{3} / \mathrm{yr}\right.$ for $1983-2003$ and $0.4 \mathrm{~km}^{3} / \mathrm{yr}$ for 2006), who assumed that all flank motion was driven by DRS. Magma compressibility and scrubbing of sulfur by Kīlauea's hydrothermal system also contribute importantly to uncertainty. Although we suspect that scrubbing is probably minor (as is usually the case where magma is at or very close to the surface), we cannot discount the possibility of significant scrubbing and are reluctant to apply a prior constraint based on our qualitative suspicions. Unsurprisingly, under the assumption of no scrubbing, we estimate eruption rates and MSRs that are lower and better resolved (Figure S1). We hope that these results will help motivate future work to resolve these critical components of Kỉlauea's magma plumbing system.

\section{Discussion}

\subsection{Is Kìlauea an Open System?}

Previous studies have suggested that Kỉlauea's supply and eruption rates tend to track one another, at least when averaged over a number of eruptions (Dvorak \& Dzurisin, 1993), and also that shallow storage rates during the ongoing $\mathrm{Pu}^{\prime} \mathrm{u}$ ' ${ }^{`}{ }^{\prime} \mathrm{o}$ eruption have usually been less than either supply or eruption rates (Johnson, 1992; Kauahikaua \& Miklius, 2003). These results have suggested that Kîlauea has been a relatively open system since at least 1983, but DRS and magma compressibility complicate the picture.

We find that the distribution of Kỉlauea's magma supply (by mass) was similar during $t_{1}$ and $t_{3}$, with less than $10 \%$ of MSR stored or withdrawn from the summit reservoir system, up to $\sim 50 \%$ entering the deep rifts, and the remainder ( $>\sim 50 \%$ ) erupted from the ERZ (Figure 6). During both time periods DRS exceeded the rate of summit storage at $>90 \%$ confidence (given our prior constraint on DRS), which leads us to conclude that although Killauea was a relatively open system, storage of magma in the deep rifts may have represented a significant fraction of supply. The situation differed during the supply surge in $t_{2}$, when high 
rates of summit storage likely matched or exceeded the rate of DRS. Distributions under the assumption of DRS at either 0 or $0.045 \mathrm{~km}^{3} / \mathrm{yr}$ are shown in Figure S2.

We define an eruption efficiency as the ratio of eruption rate to supply rate $\left(Q_{o} / Q_{i}\right.$; this differs somewhat from the definition in Wright \& Klein (2008)) and find efficiencies above $~ 50 \%$ for all time periods (Figure 6b). Efficiency decreased at $\sim 90 \%$ confidence in association with the supply surge in $t_{2}$, but this decrease was probably less than $30 \%$ (Figure 6c). Change in efficiency is not well resolved between $t_{2}$ and $t_{3}$, but we find that efficiency in $t_{3}$ was reduced from $t_{1}$ at $99.9 \%$ confidence. Computing ratios of mass summit storage rate to eruption rate $\left(Q_{s} / Q_{o}\right)$, we find that summit storage rates in $t_{3}$ were $\sim 3-9 \%$ of eruption rate, down from $\sim 13-38 \%$ in $t_{2}$. The modest decrease in efficiency and high rates of summit storage and rapid uplift in $t_{2}$ may indicate that the ERZ conduit was able to absorb some, but not all, of the increased supply during the surge. Additional variations in efficiency may have been caused by unrelated changes in K̄̄lauea's shallow magma plumbing system, which could perhaps explain why efficiency did not return to $t_{1}$ levels following the end of the surge.

\subsection{Changes in Kïlauea's Magma Flow Rates and Implications for Eruptive Activity}

Marginal posterior PDFs suggest temporal changes in magma flow rates, but computing relative changes between time periods can eliminate some constant error terms and bring changes into tighter focus. We compute an unambiguous $>99 \%$ chance of some increase in MSR between $t_{1}$ and $t_{2}$; this increase in supply was probably between $35 \%$ and $99 \%$ (Figure 5), roughly consistent (especially at the high end of the range) with the observed increase in summit $\mathrm{CO}_{2}$ emissions (Poland et al., 2012). Eruption rate likewise increased, by between $63 \%$ and $151 \%$. By $t_{3}$, Kîlauea's magma supply surge had ended; relative to $t_{2}$, MSR had decreased by $-67 \%--46 \%$ and eruption rate by $-57--14 \%$, and both parameters were decreased from $t_{1}$ at $>95 \%$ confidence. These results support the idea of a post-surge lull in supply following $t_{2}$ (Poland, 2014).

The surge and subsequent lull were clearly manifested at the surface of Kîlauea by variations in magmatic and volcanic activity. The magma supply surge was accompanied by an increase in eruption rate, resulting in a more vigorous lava flow field. Changes in the mineralogy and chemistry of erupted products were also documented, suggesting an increasing component of "fresh" mantle-derived magma within the volcano (Poland et al., 2012; Thornber et al., 2015). The eruption was unable to keep pace with the burgeoning supply of magma, however, and the rate of storage beneath the summit increased, stressing nearby faults and causing a few moderate-magnitude earthquakes (Wauthier et al., 2013). In June 2007 the magma system along the ERZ ruptured in the "Father's Day" ERZ intrusion and eruption, with the formation of new eruptive vents along the ERZ (Poland et al., 2008). 
Magmatic and eruptive activity during the magma supply lull in $t_{3}$, in contrast, was considerably subdued, even compared to pre-surge levels. Lava flows failed to reach the south coast of the island during most of 2012 (Poland, 2014), whereas ocean entries in the same area were common prior to and during the surge. Based on evidence for continued low rates of lava effusion, the MSR lull appears to have persisted into at least 2015 (although not modeled here). It is tempting to speculate that the lull in supply might therefore have influenced the ability of lava flows to advance far enough from their source vents to cause considerable damage to communities on the east side of the Island of Hawai'i during the Pāhoa lava flow crisis of 2014-2015 (Poland et al., 2016). Were supply higher, the impact on populated areas might have been more severe.

\section{Conclusions}

The technique developed in this study may be suitable for constraining magma supply rates at a variety of volcanoes for which storage and eruption rates can be probabilistically estimated. Direct measurements of ground deformation and erupted volumes from space- or air-borne platforms are suitable in this regard, and might make the technique applicable even to volcanoes without extensive ground-based monitoring networks. Where direct measurements of eruption rate are not available, proxies such as $\mathrm{SO}_{2}$ emissions may be used, but require knowledge of system properties such as the magma's volatile content and the extent of hydrothermal scrubbing of sulfur, and may therefore result in greater uncertainties. In such cases, the technique may be expected to work best at reasonably well-understood volcanoes with good monitoring networks.

Our model of Kīlauea is simple - based most fundamentally on mass conservation - but relates steadystate magma flow rates with observed ground deformation, $\mathrm{SO}_{2}$ emissions, flow field volumes, and magma composition. With this model and the Bayesian approach used in this work, we are able to quantitatively account for important sources of uncertainty that have mostly been neglected in previous studies. Despite uncertainties, changes in the rate of magma supply to Kỉlauea (by perhaps as much as a factor of 2 or more) over sub-decadal time scales are unambiguous in the context of our model. The "surge" in magma supply to Kilauea during 2006 was followed by a reduction of supply to rates that were lower than pre-surge (20002001 ) levels at $>95 \%$ confidence. Whether these changes in supply rate are quasi-random, the post-2006 lull represents a temporary equilibration following the surge, or the lower rates represent the early stages of the end of the ongoing $\mathrm{Pu}^{\prime} \mathrm{u}$ ' $\overline{\mathrm{O}}{ }^{‘} \overline{\mathrm{o}}$ eruption, remains unknown.

Although MSR to Kīlauea may be modulated by summit reservoir pressure (Dvorak \& Dzurisin, 1993; 
Gonnermann et al., 2012), the changes observed in this study were likely driven predominantly by deeper (bottom-up) processes, as suggested by petrologic data, $\mathrm{CO}_{2}$ emissions, and other observations (Poland et al., 2012). How changes in deep supply are manifested as changes in storage and eruption rates has implications for lava flow advance rates, the formation or abandonment of eruptive vents, and the intrusion of magma into country rock, but is complicated by changes in the volcano's shallow plumbing system. We find that despite substantial variations in Kīlauea's supply rate, at least half - and perhaps nearly all, depending on the rate of deep rift storage - of the magma that entered the system erupted onto the surface during all three studied time periods, and summit storage rates were generally only a fraction of eruption rates. Thus, even a minor reduction in eruption efficiency can result in greatly increased rates of summit inflation, as observed during the 2006 supply surge. Changes in efficiency may occur as a response to changes in MSR or be due to unrelated variations in the shallow magma plumbing system, but we speculate that modestly reduced efficiency during 2006 could be consistent with limitations in the carrying capacity of the ERZ conduit during the surge. Regardless of the cause, tracking probabilistic changes in magma supply, storage, and eruption rates may provide an important tool for monitoring evolving volcanic hazard.

Multiphysical volcano models, used in Bayesian inverse procedures with a wide range of data and prior information, show great promise for probabilistically illuminating otherwise difficult-to-constrain properties of volcanic systems. This work represents only a first step in the use of this approach at Kīlauea. Estimates of magma flow rates at the volcano must be updated and refined as new observations become available, as understanding of the volcanic system improves, and as the volcano model is further developed. We emphasize the importance of future work on Kīlauea's mobile south flank, as well as alternative means of quantifying lava discharge rate, since significant uncertainty in rates of deep rift storage and eruption translate into significant uncertainty in magma supply rates. If storage and eruption rates can be estimated over shorter time periods it should be possible to estimate MSR with correspondingly improved temporal resolution, with the caveat that propagation delays of magma throughout the system place a lower bound on the time durations over which simple models such as the one developed in this study may be used. Our volcano model is straightforward, fast, and robust, requiring relatively few complex (and often poorly-understood) physical processes to be directly modeled. In the future it will be useful to include additional physical processes, such as the effect of volatiles on magma compressibility, which will relate model parameters in ways not currently considered. 


\section{Acknowledgments}

404

We thank the scientists and staff of the USGS Hawaiian Volcano Observatory for their work gathering and interpreting the data on which studies such as this are based. Discussions with Jeff Sutton, Marie Edmonds, and others, and reviews by Roger Denlinger, Andy Hooper, and one anonymous reviewer, materially improved the quality of this manuscript. This work was supported by the USGS Mendenhall Research

Fellowship Program. Any use of trade, firm, or product names is for descriptive purposes only and does not

409 imply endorsement by the U.S. Government. 
Anderson, K., \& Segall, P. (2011).

Physics-based models of ground deformation and extrusion rate at effusively erupting volcanoes. Journal of Geophysical Research: Solid Earth, 116, B07204. URL: http://www.agu.org/pubs/crossref/2011/2010JB007939.shtml http://doi.wiley.com/10.1029/2010JB007939. doi:10.1029/2010JB007939.

Anderson, K., \& Segall, P. (2013). Bayesian inversion of data from effusive volcanic eruptions using physics-based models: Application to Mount St. Helens 2004-2008. Journal of Geophysical Research: Solid Earth, 118, 2017-2037. URL: http://doi.wiley.com/10.1002/jgrb.50169. doi:10.1002/jgrb.50169.

Baker, S., \& Amelung, F. (2012). Top-down inflation and deflation at the summit of Kīlauea Volcano, Hawaii observed with InSAR. Journal of Geophysical Research: Solid Earth, 117, B12406. URL: http://www.agu.org/pubs/crossref/2012/2011JB009123.shtml. doi:10.1029/2011JB009123.

Baker, S., \& Amelung, F. (2015). Pressurized magma reservoir within the east rift zone of Kīlauea volcano, Hawaii: Evidence for relaxed stress changes from the 1975 Kalapana earthquake. Geophysical Research Letters, 42, $1758-1765$. doi:10.1002/2015GL063161.

Cayol, V., Dieterich, J. H., Okamura, A. T., \& Miklius, A. (2000). High magma storage rates before the 1983 eruption of Kilauea, Hawaii. Science, 288, 2343-2346. URL: http://www.ncbi.nlm.nih.gov/pubmed/10875914 http://www.sciencemag.org/cgi/doi/10.1126/science.288.5475.2343. doi:10.1126/science.288.5475.2343.

Cervelli, P. F., \& Miklius, A. (2003). The shallow magmatic system of Kīlauea Volcano. In C. Heliker, D. Swanson, \& J. T. Takahashi (Eds.), The Pu'u 'Ō'ō-Kupaianaha Eruption of Kīlauea Volcano, Hawai'i: The First 20 Years (pp. 149-164). U.S. Geological Survey Professional Paper 1676.

Denlinger, R. P. (1997). A dynamic balance between magma supply and eruption rate at Kilauea volcano, Hawaii. Journal of Geophysical Research: Solid Earth, 102, 18091-18100. URL: http://doi.wiley.com/10.1029/97JB01071 http://www. agu.org/pubs/crossref/1997/97JB01071.shtml. doi:10.1029/97JB01071.

Denlinger, R. P., \& Morgan, J. K. (2014). Instability of Hawaiian Volcanoes. In M. P. Poland, J. T. Takahashi, \& C. M. Landowski (Eds.), Characteristics of Hawaiian Volcanoes chapter 4. (pp. 149-176). U.S. Geological Survey Professional Paper 1801.

Dvorak, J. J., \& Dzurisin, D. (1993). Variations in magma supply rate at Kilauea Volcano, Hawaii. Journal of Geophysical Research: Solid Earth, 98, 22255-22268. URL: http://doi.wiley.com/10.1029/93JB02765. doi:10.1029/93JB02765.

Dzurisin, D., Anderson, L. A., Eaton, G. P., Koyanagi, R. Y., Lipman, P. W., Lockwood, J. P., Okamura, R. T., Puniwai, G. S., Sako, M. K., \& Yamashita, K. M. (1980). Geophysical observations of Kilauea Volcano, Hawaii, 2. Constraints on the magma supply during November 1975-September $1977 . \quad$ Journal of Volcanology and Geothermal Research, 7, 241-269. URL: http://www.sciencedirect.com/science/article/pii/0377027380900323 http://linkinghub.elsevier.com/retrieve/pii/0377027380900323. doi:10.1016/0377-0273(80)90032-3.

Eaton, J. P., \& Murata, K. J. (1960). How volcanoes grow. Science, 132, 925-38. URL: http://www.ncbi.nlm.nih.gov/pubmed/17795159. doi:10.1126/science.132.3432.925.

Elias, T., \& Sutton, A. J. (2007). Sulfur dioxide emission rates from Kūlauea Volcano, Hawaii, an update: 2002-2006. U.S. Geological Survey Open File Report 2007-1114.

Elias, T., \& Sutton, A. J. (2012). Sulfur dioxide emission rates from Kīlauea Volcano, Hawai`i, 2007-2010. U.S. Geological Survey Open File Report 2012-1107.

Gonnermann, H. M., Foster, J. H., Poland, M., Wolfe, C. J., Benjamin, A., Miklius, A., Brooks, B. A., \& Miklius, A. (2012). 
Coupling at Mauna Loa and Kīlauea by stress transfer in an asthenospheric melt layer. Nature Geoscience, 5, 826-829. URL: http://dx.doi.org/10.1038/ngeo1612 http://www.nature.com/doifinder/10.1038/ngeo1612. doi:10.1038/ngeo1612.

Greenland, L., Rose, W., \& Stokes, J. (1985). An estimate of gas emissions and magmatic gas content from Kilauea volcano. Geochimica et Cosmochimica Acta, 49, 125-129. URL: http://linkinghub.elsevier.com/retrieve/pii/0016703785901966. doi:10.1016/0016-7037(85)90196-6.

Heliker, C., \& Mattox, T. (2003). The first two decades of the $\mathrm{Pu}^{\prime} \mathrm{u}$ ' $\overline{\mathrm{O}}$ ' $\mathrm{o}-\mathrm{Kupaianaha}$ eruption: Chronology and selected bibliography. In C. Heliker, D. A. Swanson, \& J. T. Takahashi (Eds.), The Pu'u 'Ō'o-Kupaianaha Eruption of Kūlauea Volcano, Hawai'i: The First 20 Years. U.S. Geological Survey Professional Paper 1676.

Johnson, D. J. (1992). Dynamics of magma storage in the summit reservoir of Kilauea Volcano, Hawaii. Journal of Geophysical Research: Solid Earth, 97, 1807-1820. URL: http://europa.agu.org/?uri=/journals/jb/91JB02839.xml\&view=article http://www. agu.org/pubs/crossref/1992/91JB02839.shtml. doi:10.1029/91JB02839.

Johnson, D. J., Sigmundsson, F., \& Delaney, P. T. (2000). Comment on "Volume of magma accumulation or withdrawal estimated from surface uplift or subsidence, with application to the 1960 collapse of Kîlauea volcano" by P. T. Delaney and D. F. McTigue. Bulletin of Volcanology, 61, 491-493. URL: http://link.springer.com/10.1007/s004450050006. doi:10.1007/s004450050006.

Kauahikaua, J., \& Miklius, A. (2003). Long-term trends in microgravity at Kīlauea's summit during the Pu‘u 'Ō‘̄̄-Kupaianaha eruption. In C. Heliker, D. A. Swanson, \& T. J. Takahashi (Eds.), The Pu'u 'Ō'ō-Kupaianaha Eruption of Kīlauea Volcano, Hawai' $i$ : The First 20 Years (pp. 165-172). U.S. Geological Survey Professional Paper 1676.

Klein, Fred W., \& Wright, Thomas L. (in review). Magma supply and transport at Kīlauea Volcano, Hawa'i: a review of the last 200 years. Bulletin of Volcanology

Miklius, A., \& Cervelli, P. (2003). Interaction between Kilauea and Mauna Loa. Nature, 421, 229-229. URL: http://www. nature.com/doifinder/10.1038/421229a. doi:10.1038/421229a.

Mogi, K. (1958). Relations between the eruptions of various volcanoes and the deformations of the ground surfaces around them. Bull. Earthquake Res. Inst. University of Tokyo, 36, 99-134.

Mosegaard, K., \& Tarantola, A. (1995). Monte Carlo sampling of solutions to inverse problems. Journal of Geophysical Research: Solid Earth, 100, 12431-12447. URL: http://www.agu.org/pubs/crossref/1995/94JB03097.shtml http://doi.wiley.com/10.1029/94JB03097. doi:10.1029/94JB03097.

Myer, D., Sandwell, D., Brooks, B., Foster, J., \& Shimada, M. (2008). Inflation along Kilauea's Southwest Rift Zone in 2006. Journal of Volcanology and Geothermal Research, 177, 418-424. URL: http://linkinghub.elsevier.com/retrieve/pii/S0377027308003430 http://dx.doi.org/10.1016/j.jvolgeores.2008.06.006. doi:10.1016/j.jvolgeores.2008.06.006.

Okada, Y. (1985). Surface deformation due to shear and tensile faults in a half-space. Bulletin of the Seismological Society of America, 75, 1135-1154.

Okamura, A. T., Dvorak, J. J., Koyanagi, R. Y., \& Tanigawa, W. R. (1988). Surface deformation during dike propagation. In The Puu Oo eruption of Kilauea Volcano, Hawaii; episodes 1 through 20, January 3, 1983, through June 8, 1984 (pp. 165-181). U.S. Geological Survey Professional Paper 1463.

Orr, T. R., Bleacher, J. E., Patrick, M. R., \& Wooten, K. M. (2015). A sinuous tumulus over an active lava tube at Kīlauea Volcano: Evolution, analogs, and hazard forecasts. Journal of Volcanology and Geothermal Research, 291, 35-48. URL: http://dx.doi.org/10.1016/j.jvolgeores.2014.12.002 
http://linkinghub.elsevier.com/retrieve/pii/S037702731400376X. doi:10.1016/j.jvolgeores.2014.12.002.

Orr, T. R., Thelen, W. A., Patrick, M. R., Swanson, D. A., \& Wilson, D. C. (2012). Explosive eruptions triggered by rockfalls at Kīlauea volcano, Hawai'i. Geology, 41, 207-210. URL: http://geology.gsapubs.org/cgi/doi/10.1130/G33564.1. doi:10.1130/G33564.1.

Owen, S., Segall, P., Lisowski, M., Miklius, A., Denlinger, R., \& Sako, M. (2000). Rapid deformation of Kilauea Volcano: Global Positioning System measurements between 1990 and $1996 . \quad$ Journal of Geophysical Research: Solid Earth, 105, 18983-18998. URL: http://doi.wiley.com/10.1029/2000JB900109 http://www.agu.org/pubs/crossref/2000/2000JB900109.shtml. doi:10.1029/2000JB900109.

Patrick, M. R., Anderson, K. R., Poland, M. P., Orr, T. R., \& Swanson, D. A. (2015). Lava lake level as a gauge of magma reservoir pressure and eruptive hazard. Geology, 43, 831-834. URL: http://geology.gsapubs.org/lookup/doi/10.1130/G36896.1. doi:10.1130/G36896.1.

Poland, M., Miklius, A., Orr, T., \& Sutton, J. (2008). New episodes of volcanism at Kilauea Volcano, Hawaii. Eos, 89, 37-48. URL: http://volcanoes.usgs.gov/activity/methods/insar/public_files/Poland_10.pdf.

Poland, M. P. (2014). Time-averaged discharge rate of subaerial lava at Kīlauea Volcano, Hawaii, measured from TanDEM-X interferometry: Implications for magma supply and storage during 2011-2013. Journal of Geophysical Research: Solid Earth, 119, 5464-5481. URL: http://doi.wiley.com/10.1002/2014JB011132. doi:10.1002/2014JB011132.

Poland, M. P., Miklius, A., Jeff Sutton, A., \& Thornber, C. R. (2012). A mantle-driven surge in magma supply to Kīlauea Volcano during 2003-2007. Nature Geoscience, 5, 295-300. URL: http://www.nature.com/doifinder/10.1038/ngeo1426. doi:10.1038/ngeo1426.

Poland, M. P., Miklius, A., \& Montgomery-Brown, E. K. (2014). Magma supply, storage, and transport at shield-stage Hawaiian volcanoes. In M. P. Poland, T. J. Takahashi, \& C. M. Landowski (Eds.), Characteristics of Hawaiian Volcanoes (pp. 179-234). U.S. Geological Survey Professional Paper 1801. doi:10.3133/pp1801.

Poland, M. P., Orr, T. R., Kauahikaua, J. P., Brantley, S. R., Babb, J. L., Patrick, M. R., Neal, C. A., Anderson, K. R., Antolik, L., Burgess, M., Elias, T., Fuke, S., Fukunaga, P., Johanson, I. A., Kagimoto, M., Kamibayashi, K., Lee, L., Miklius, A., Million, W., Moniz, C., Okubo, P. G., Sutton, A. J., Takahashi, T. J., Thelen, W. A., Tollett, W., \& Trusdell, F. A. (2016). The 2014-2015 Pāhoa lava flow crisis at Kīlauea Volcano, Hawaii: Disaster avoided and lessons learned. GSA Today, 26, 4-10. URL: http://www.geosociety.org/gsatoday/archive/26/2/abstract/i1052-5173-26-2-4.htm. doi:10.1130/GSATG262A.1.

Rivalta, E., \& Segall, P. (2008). Magma compressibility and the missing source for some dike intrusions. Geophysical Research Letters, 35, L04306. URL: http://doi.wiley.com/10.1029/2007GL032521 http://www.agu.org/pubs/crossref/2008/2007GL032521.shtml. doi:10.1029/2007GL032521.

Robinson, J. E., \& Eakins, B. W. (2006). Calculated volumes of individual shield volcanoes at the young end of the Hawaiian Ridge. Journal of Volcanology and Geothermal Research, 151, 309-317. doi:10.1016/j.jvolgeores.2005.07.033.

Rowe, M. C., Thornber, C. R., \& Orr, T. R. (2015). Primitive components, crustal assimilation, and magmatic degassing during the early 2008 Kīlauea summit eruptive activity. In R. Carey, V. Cayol, M. Poland, \& D. Weis (Eds.), Hawaiian Volcanoes: From Source to Surface chapter 20. (pp. 439-455). AGU Geophysical Monograph 208. URL: http://doi.wiley.com/10.1002/9781118872079.ch8 http://doi.wiley.com/10.1002/9781118872079.ch20. doi:10.1002/9781118872079.ch20.

Ryan, M. P. (1988). The mechanics and three-dimensional internal structure of active magmatic sys- 
tems: Kilauea Volcano, Hawaii. Journal of Geophysical Research: Solid Earth, 93, 4213-4248. URL: http://www.agu.org/pubs/crossref/1988/JB093iB05p04213.shtml. doi:10.1029/JB093iB05p04213.

Sutton, A., Elias, T., Kauahikaua, J., \& Sutton, B. A. J. (2003). Lava-effusion rates for the Pu'u 'Ō'̄o-Kupaianaha eruption derived from $\mathrm{SO}_{2}$ emissions and very low frequency (VLF) measurements. In C. Heliker, D. A. Swanson, \& T. J. Takahashi (Eds.), The Pu'u 'Ō'o-Kupaianaha Eruption of Kīlauea Volcano, Hawai' $i$ : The First 20 Years (pp. 137-148). U.S. Geological Survey Professional Paper 1676.

Swanson, D. A. (1972). Magma supply rate at Kilauea Volcano, 1952-1971. Science, 175, 169-70. URL: http://www.ncbi.nlm.nih.gov/pubmed/17771801. doi:10.1126/science.175.4018.169.

Teplow, W., Marsh, B., Hulen, J., Spielman, P., Kaleikini, M., Fitch, D., \& Rickard, W. (2009). Dacite melt at the Puna Geothermal Venture wellfield, Big Island of Hawaii. Transactions - Geothermal Resources Council, 33, 989-994.

Thornber, C. R., Heliker, C., Sherrod, D. R., Kauahikaua, J. P., Miklius, A., Okubo, P. G., Trusdell, F. A., Budahn, J. R., Ridley, W. I., \& Meeker, G. P. (2003). Kilauea East Rift Zone magmatism: an Episode 54 perspective. Journal of Petrology, 44, 1525-1559. URL: http://www.petrology.oupjournals.org/cgi/doi/10.1093/petrology/egg048. doi:10.1093/petrology/egg048.

Thornber, C. R., Orr, T. R., Heliker, C., \& Hoblitt, R. P. (2015). Petrologic testament to changes in shallow magma storage and transport during 30+ years of recharge and eruption at Kīlauea Volcano, Hawaii. In R. Carey, V. Cayol, M. Poland, \& D. Weis (Eds.), Hawaiian Volcanoes: From Source to Surface chapter 8. (pp. 147-188). AGU Geophysical Monograph 208. URL: http://doi.wiley.com/10.1002/9781118872079.ch8. doi:10.1002/9781118872079.ch8.

Tilling, R. I., Christiansen, R. L., Duffield, W. A., Endo, E. T., Holcomb, R. T., Koyanagi, R. Y., Peterson, D. W., \& Unger, J. D. (1987). The 1972-1974 Mauna Ulu eruption, Kilauea Volcano: An example of quasi-steady-state magma transfer. In R. W. Decker, T. L. Wright, \& P. H. Stauffer (Eds.), Volcanism in Hawaii, Vol 1 chapter 16. (pp. 405-469). U.S. Geological Survey Professional Paper 1350

Wauthier, C., Roman, D. C., \& Poland, M. P. (2013). Moderate-magnitude earthquakes induced by magma reservoir inflation at Kīlauea Volcano, Hawaii. Geophysical Research Letters, 40, 5366-5370. URL: http://doi.wiley.com/10.1002/2013GL058082. doi:10.1002/2013GL058082.

Wolfe, C. J., Solomon, S. C., Laske, G., Collins, J. A., Detrick, R. S., Orcutt, J. A., Bercovici, D., \& Hauri, E. H. (2009). Mantle shear-wave velocity structure beneath the Hawaiian hot spot. Science, 326, 1388-90. URL: http://www.ncbi.nlm.nih.gov/pubmed/19965755. doi:10.1126/science.1180165.

Wolfe, E. W., Garcia, M. O., Jackson, D. E., Koyanagi, R. Y., Neal, C. A., \& Okamura, A. T. (1987). The Puu Oo eruption of Kilauea Volcano, episodes 1-20, January 3, 1983, to June 8, 1984. In Volcanism in Hawaii, Vol 1 (pp. 471-508). U.S. Geological Survey Professional Paper 1350.

Wright, T. L., \& Klein, F. W. (2008). Dynamics of magma supply to Kīlauea volcano, Hawai'i: integrating seismic, geodetic and eruption data. In C. Annen, \& G. F. Zellmer (Eds.), Dynamics of Crustal Magma Transfer, Storage and Differentiation (pp. 83-116). Geological Society, London volume 304. URL: http://sp.lyellcollection.org/cgi/doi/10.1144/SP304.5. doi:10.1144/SP304.5

Wright, T. L., \& Klein, F. W. (2014). Two hundred years of magma transport and storage at Kīlauea Volcano, Hawaii, 1790-2008. U.S. Geological Survey Professional Paper 1806. doi:10.3133/pp1806. 
Table 1: Time periods used in this study and primary source of constraint on summit deformation and eruption rate.

\begin{tabular}{llcll}
\hline Name & Time period & $\Delta t$ (days) & Summit Deformation & Eruption rate \\
\hline$t_{1}$ & 01 Jan 2000 - 31 Dec 2001 & 730 & Prior from Cervelli \& Miklius (2003) & Pior constraint \\
$t_{2}$ & 11 Dec 2005 - 31 Dec 2006 & 385 & InSAR (ENVISAT) & SO $_{2}$ emissions \\
$t_{3}$ & 20 Oct 2011 - 16 May 2012 & 208 & InSAR (COSMO-SkyMed) & TanDEM-X \\
\hline
\end{tabular}

Table 2: Model parameters and symbols

\begin{tabular}{lll}
\hline Symbol & Description & Units \\
\hline Model parameter and data & \\
$Q, q$ & Magma flow rate (mass, volume) & $\mathrm{kg} / \mathrm{s}, \mathrm{m}^{3} / \mathrm{s}$ \\
$Q^{s}$ & Sulfur flow rate (mass) & $\mathrm{kg} / \mathrm{s}$ \\
$\rho$ & Magma density & $\mathrm{kg} / \mathrm{m}^{3}$ \\
$V^{\prime}$ & Reservoir volume change rate & $\mathrm{m}^{3} / \mathrm{s}$ \\
$R$ & Compressibility ratio & - \\
$\mathbf{u}^{\prime}$ & Ground displacement rate & $\mathrm{cm} / \mathrm{yr}$ \\
$\xi$ & Reservoir location & $\mathrm{m}$ \\
$\mathbf{x}$ & Deformation observation coordinates & $\mathrm{m}$ \\
$\mathbf{g}$ & Reservoir model parameters (vector) & - \\
$k_{r}$ & Rift/magma scaling factor & - \\
$E^{S O_{2}}$ & SO ${ }_{2}$ emission rate & $\mathrm{kg} / \mathrm{s}$ \\
$\chi^{S}$ & Sulfur concentration & $\mathrm{wt} \%$ \\
\hline Location & symbols (subscripts) & \\
$i$ & Inflow (supply) & - \\
$s$ & Summit storage & - \\
$r$ & Rift storage & - \\
$o$ & Outflow (eruption) & - \\
$s b$ & Scrubbing & - \\
$e s$ & Erupted at summit & - \\
$e e$ & Erupted in ERZ & - \\
\hline
\end{tabular}

Table 3: Magma flow rates. Median of accepted samples, and $68 \%$ and $95 \%$ confidence bounds for magma supply, summit storage, and eruption rates. Volumetric eruption rates are dense-rock equivalent (DRE); tons are metric. For consistency, all volumetric results are presented in $\mathrm{m}^{3} / \mathrm{s}$.

\begin{tabular}{|c|c|c|c|c|c|c|}
\hline Time & $\begin{array}{l}\text { Median } \\
\text { (tons/s) }\end{array}$ & $\begin{array}{l}68 \% \\
\text { (tons/s) }\end{array}$ & $\begin{array}{l}95 \% \\
\text { (tons/s) }\end{array}$ & $\begin{array}{l}\text { Median } \\
\left(\mathrm{m}^{3} / \mathrm{s}\right)\end{array}$ & $\begin{array}{l}68 \% \\
\left(\mathrm{~m}^{3} / \mathrm{s}\right)\end{array}$ & $\begin{array}{l}95 \% \\
\left(\mathrm{~m}^{3} / \mathrm{s}\right)\end{array}$ \\
\hline \multicolumn{7}{|l|}{ MSR } \\
\hline$t_{1}$ & 12.22 & {$[9.71,14.83]$} & {$[7.65,17.30]$} & 4.36 & {$[3.46,5.31]$} & {$[2.72,6.24]$} \\
\hline$t_{2}$ & 19.72 & {$[15.68,24.67]$} & {$[12.29,30.90]$} & 7.05 & {$[5.59,8.84]$} & {$[4.37,11.10]$} \\
\hline$t_{3}$ & 8.39 & {$[6.66,10.31]$} & {$[5.81,11.67]$} & 3.00 & {$[2.38,3.69]$} & {$[2.06,4.21]$} \\
\hline \multicolumn{7}{|c|}{ Summit storage rate } \\
\hline$t_{1}$ & -0.19 & {$[-0.42,-0.04]$} & {$[-0.68,0.11]$} & -0.07 & {$[-0.16,-0.02]$} & {$[-0.26,0.04]$} \\
\hline$t_{2}$ & 3.36 & {$[1.88,4.86]$} & {$[1.30,5.78]$} & 1.29 & {$[0.73,1.87]$} & {$[0.50,2.21]$} \\
\hline$t_{3}$ & 0.32 & {$[0.18,0.49]$} & {$[0.12,0.66]$} & 0.12 & {$[0.07,0.19]$} & {$[0.04,0.26]$} \\
\hline \multicolumn{7}{|c|}{ Eruption rate } \\
\hline$t_{1}$ & 9.88 & {$[7.94,11.87]$} & {$[6.50,13.70]$} & 3.53 & {$[2.83,4.26]$} & {$[2.31,4.94]$} \\
\hline$t_{2}$ & 13.66 & {$[10.29,18.17]$} & {$[7.68,24.09]$} & 4.88 & {$[3.67,6.51]$} & {$[2.73,8.65]$} \\
\hline$t_{3}$ & 5.58 & {$[5.21,5.93]$} & {$[4.94,6.21]$} & 1.99 & {$[1.85,2.14]$} & {$[1.73,2.28]$} \\
\hline
\end{tabular}



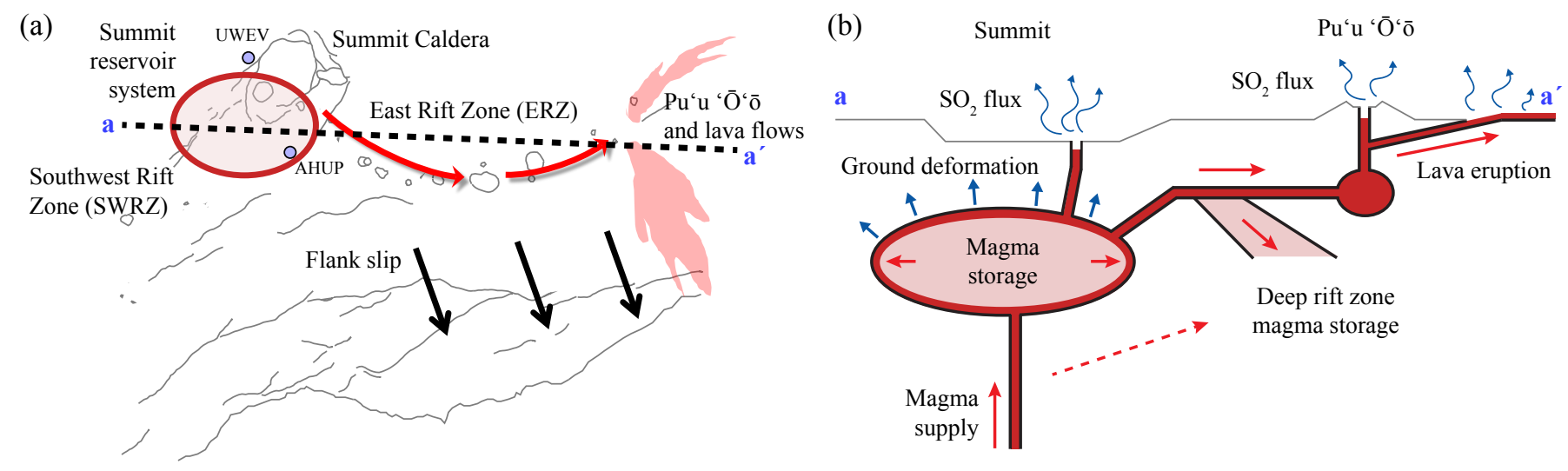

Figure 1: Map of Kīlauea's summit (a) and schematic cross section (b) showing conceptual model geometry. Magma transport and storage regions and lava flows are schematic only. Dashed line in (b) indicates possible alternate path of magma into the deep rift (both are consistent with the mathematical model design). The lava lake shown in (b) did not exist prior to 2008.

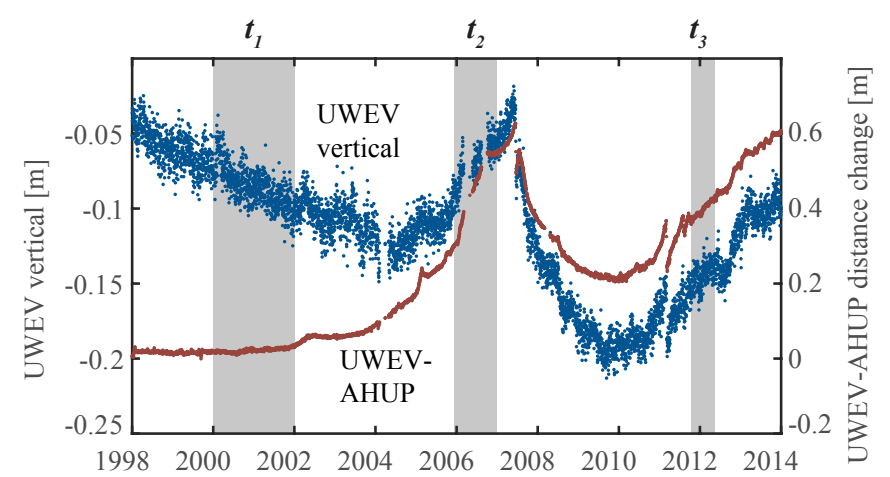

Figure 2: Summit deformation and relationship to time periods examined in this study (shaded gray bars). GPS station locations are shown in Figure 1. 

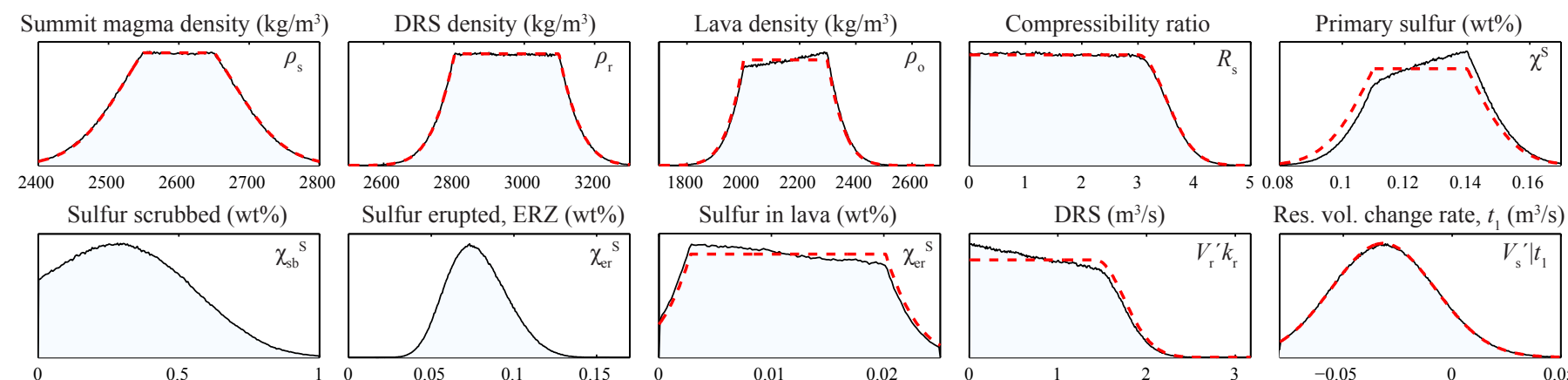

Res. vol. change rate, $t_{1}\left(\mathrm{~m}^{3} / \mathrm{s}\right)$

Res. vol. change rate, $t_{2}\left(\mathrm{~m}^{3} / \mathrm{s}\right)$ Res. vol. change rate, $t_{3}\left(\mathrm{~m}^{3} / \mathrm{s}\right)$
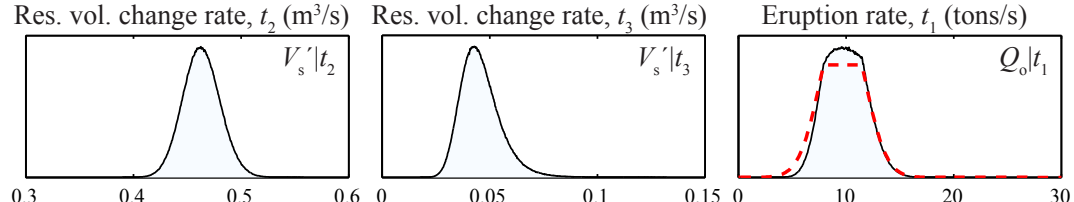

Eruption rate, $t_{2}$ (tons/s)
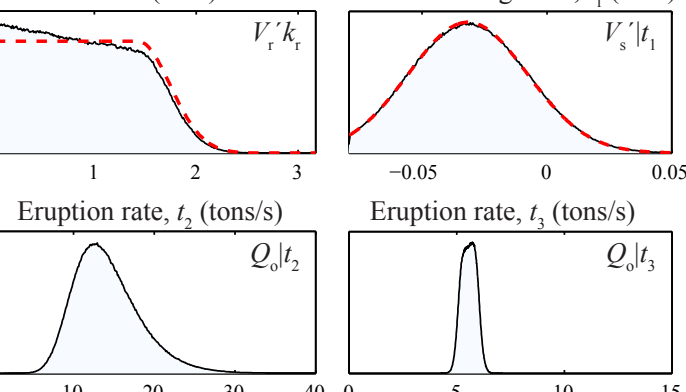

Eruption rate, $t_{3}$ (tons/s)
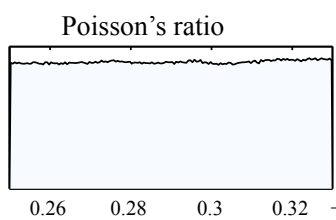

Sill length (m)

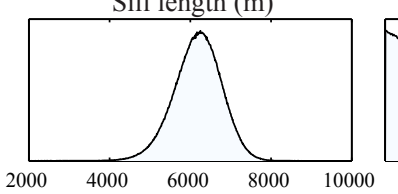

Sill east $(\mathrm{m})$

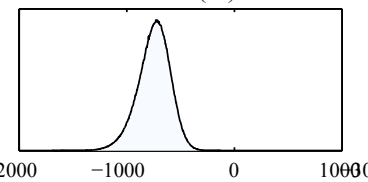

Sill width (m)

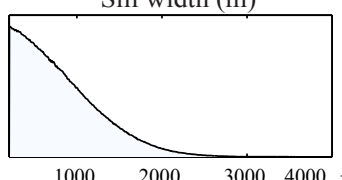

Sill north (m)

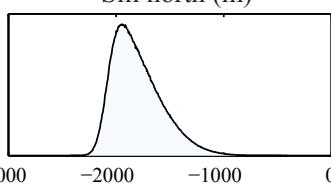

Chamber east $(\mathrm{m})$

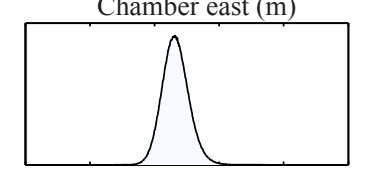

Sill depth (m)
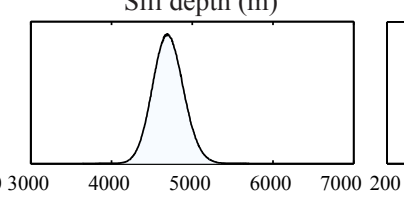

Chamber north (m)

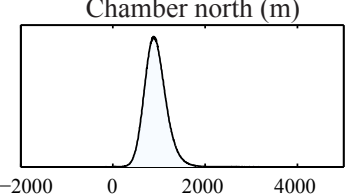

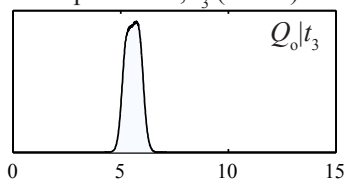

Sill strike (deg.)

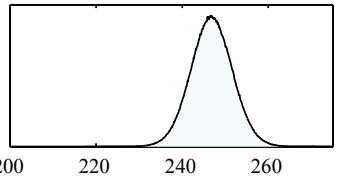

Chamber depth (m)

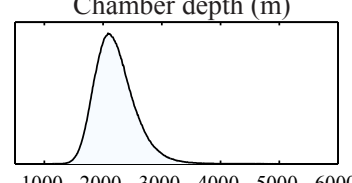

Figure 3: Posterior PDFs (defined in Supplementary Material) for all 25 estimated model parameters, with prior PDFs shown by dotted red lines (uniform prior PDFs, which are nonzero within the figures and zero outside them, are not shown). Vertical axes indicate relative probability, which is not scaled between parameters. Limits of horizontal axes correspond to $a$ priori lower and upper bounds. Model and data cannot hope to constrain many model parameters such as magma density $\rho$ (note that posterior PDFs are unchanged from prior PDFs), but by estimating these parameters their uncertainty is incorporated into estimates of other important model parameters such as MSR. "Sill" and "chamber" parameters are associated with deformation sources during $t_{2}$ and $t_{3}$, respectively ( $\xi$ and $\mathrm{g}$ in Equation (4)), and east and north positions are given relative to $19.4047^{\circ} \mathrm{N}$, $155.2805^{\circ} \mathrm{W}$, roughly the SE margin of the active lava lake during 2012. Sill coordinates reference a point at the center of the north (long) edge, and strike is degrees clockwise from north. 
(a)

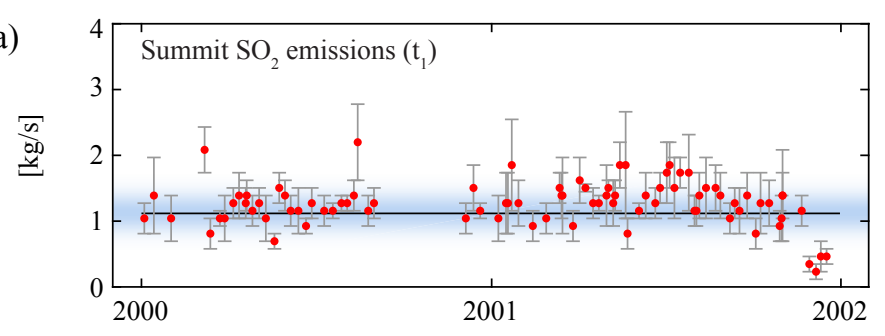

(b)

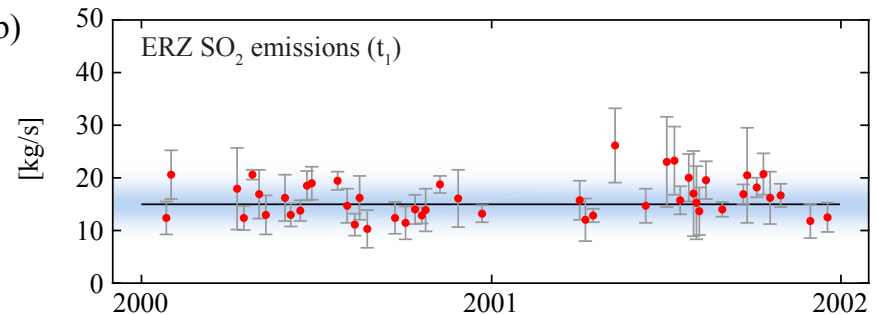

(c)
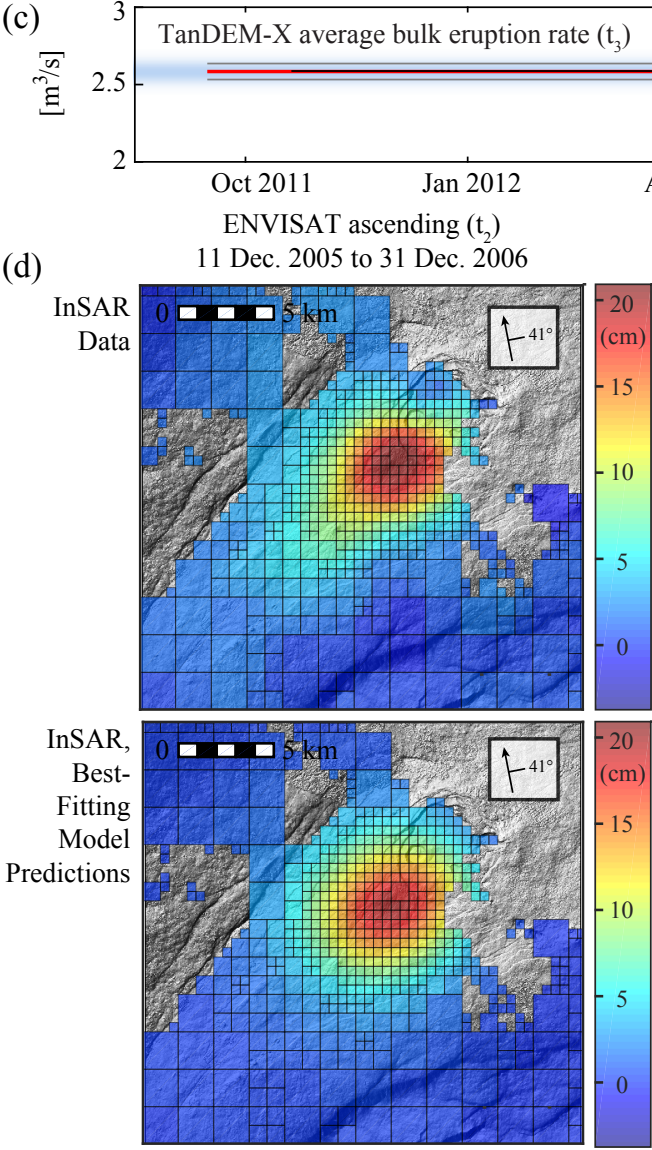
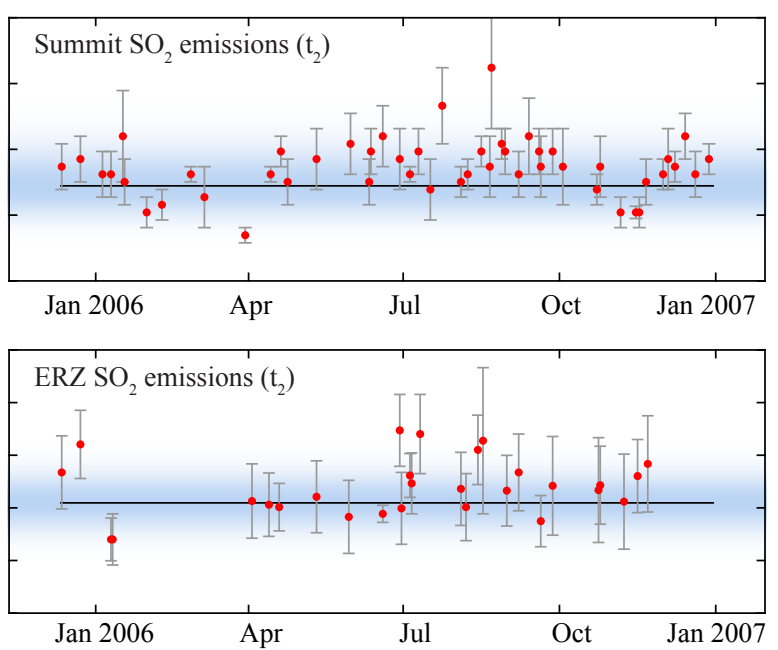

Data $\quad$ Model predictions $\quad$ Mosterior PDF
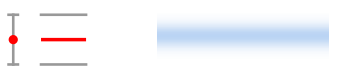

COSMO-SkyMed descending $\left(\mathrm{t}_{3}\right)$ 20 Oct. 2011 to 15 May 2012
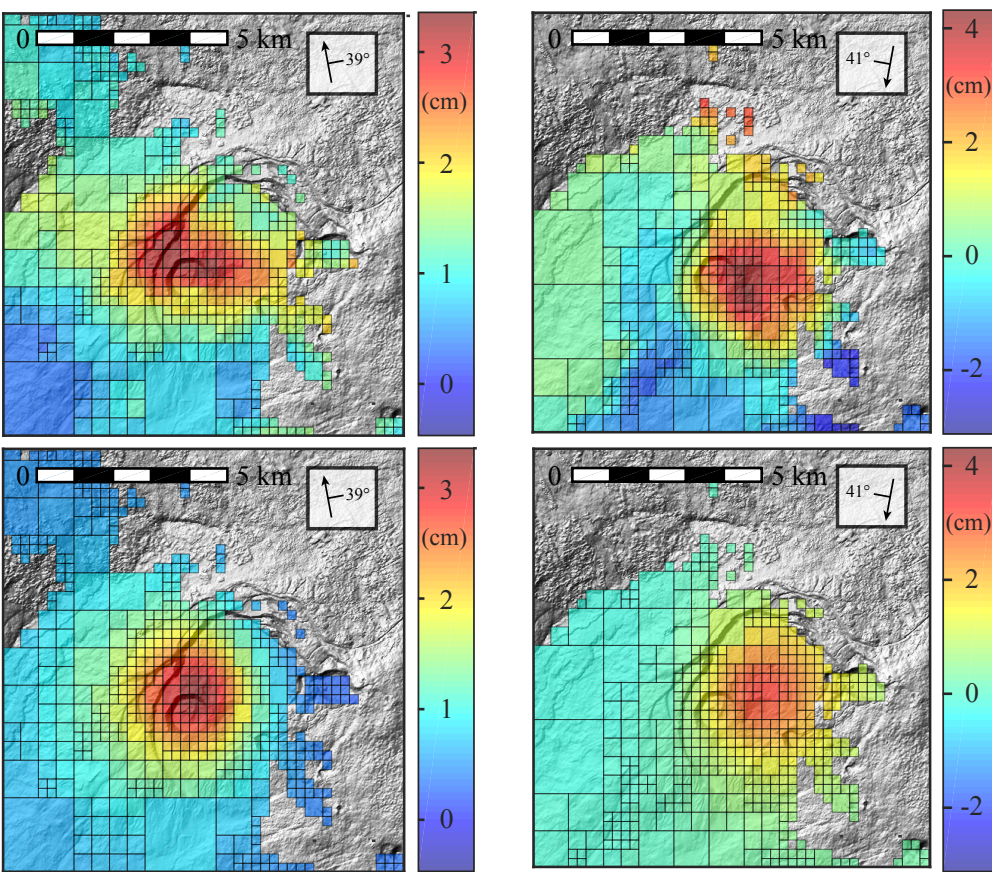

Figure 4: Fit of model predictions to data. The range of MCMC predictions are shown by horizontal blue bars in (a)-(c); because the forward model is steady-state, all rates that it predicts are constant within each time period. (a) $\mathrm{Summit}^{\mathrm{SO}_{2}}$ emissions during $t_{1}$ and $t_{2}$. (b) ERZ SO $\mathrm{SO}_{2}$ emissions during $t_{1}$ and $t_{2}$. (c) TanDEM-X time-averaged bulk eruption rate during $t_{3}$. (d) Observed InSAR displacements in the direction of the satellite (top row) and maximum-probability predictions of InSAR displacements (bottom row) for $t_{2}$ (first column) and $t_{3}$ (second and third columns). Orthogonal arrows show satellite flight and look directions. InSAR data are decimated using the quadtree algorithm (section S3.1). 
(a) Eruption Rate
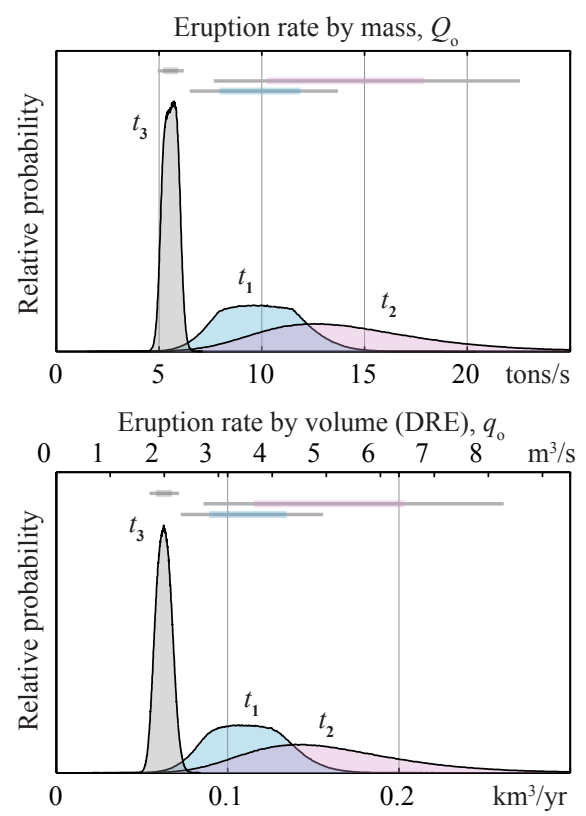

Change in eruption rate by mass
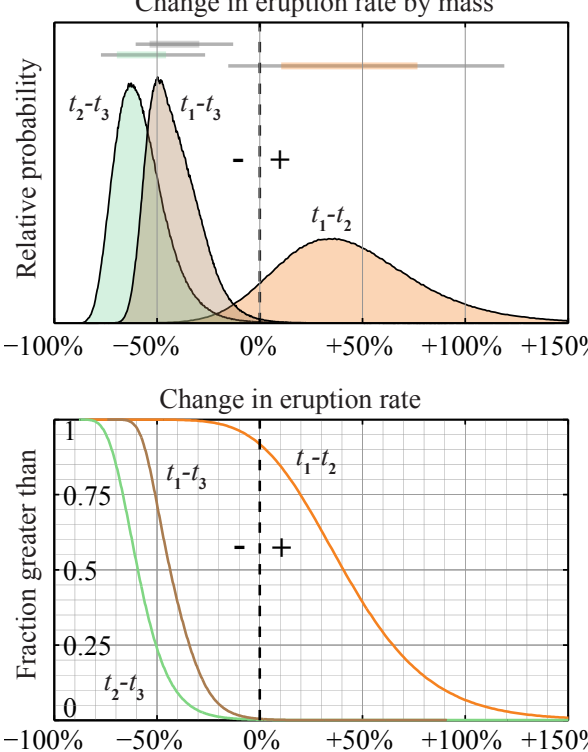

(b) Storage Rate of Magma at Summit

Magma storage at summit by mass, $Q_{\mathrm{s}}$

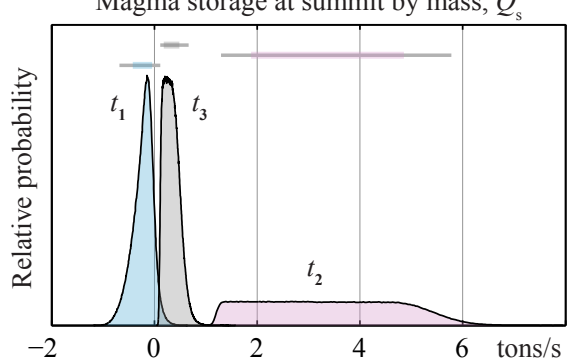

Magma storage at summit by volume, $q$

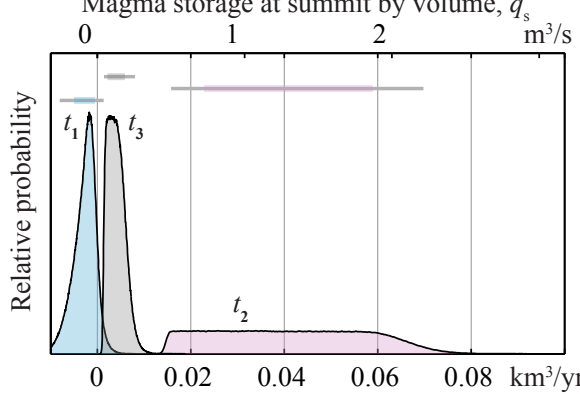

Change in rate of summit storage by mass
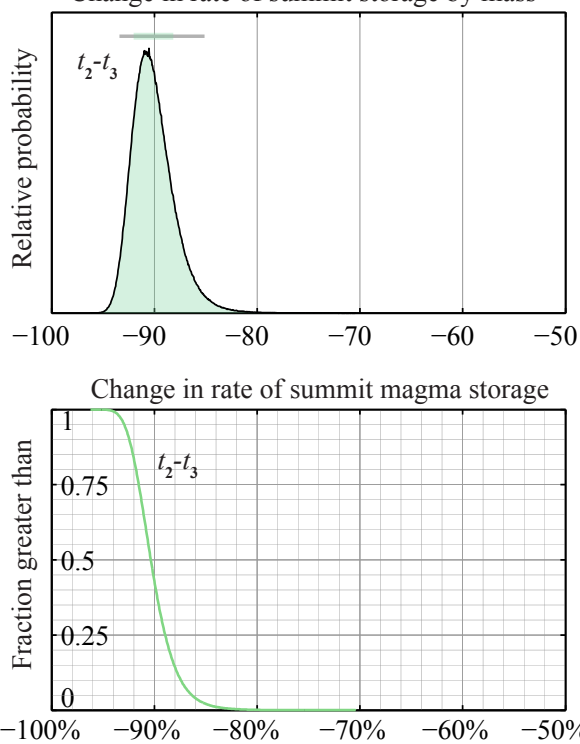

(c) Magma Supply Rate (MSR)

MSR by mass, $Q_{\text {i }}$

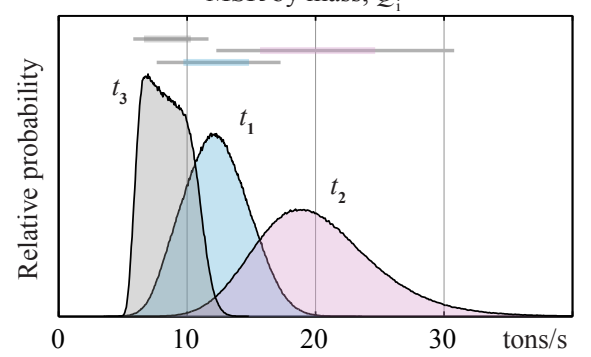

MSR by volume, $q$

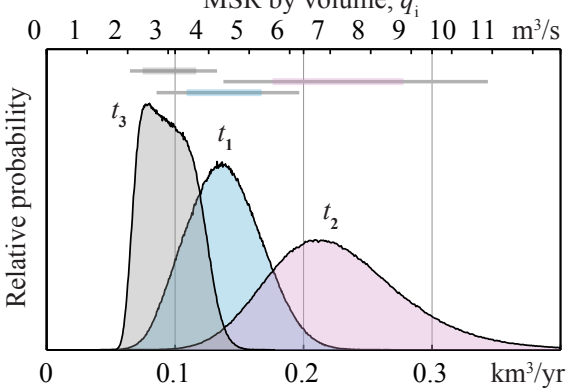

Change in MSR by mass
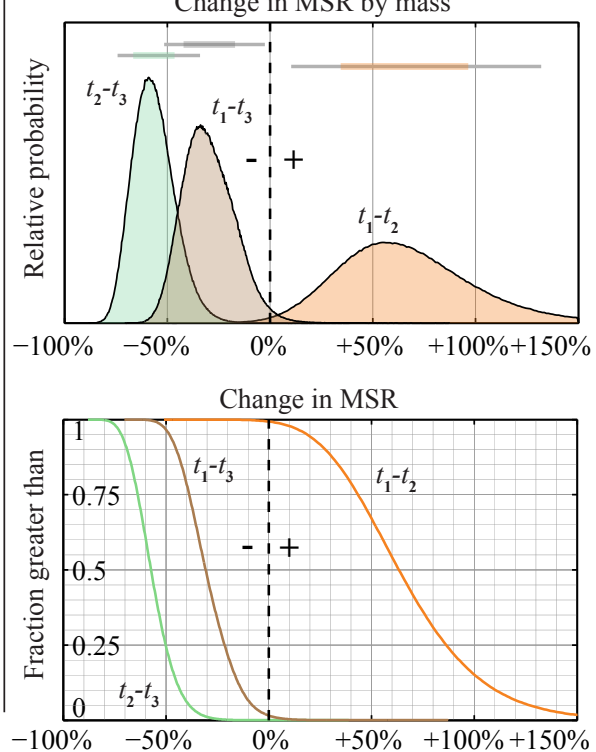

Figure 5: (a) Eruption rates, (b) summit storage rates, and (c) magma supply rates. First and second rows show posterior PDFs for mass and volumetric flux rates, respectively (eruption rate is DRE). Colored and gray horizontal bars above PDFs show $68 \%$ and $95 \%$ confidence bounds, respectively. Third row shows PDFs of relative changes in flow rates between the three studied time periods (only $t_{2}$ to $t_{3}$ is shown for storage rates since storage in $t_{1}$ is negative). Fourth row shows complimentary cumulative distribution functions, which indicate the probability that a change in flow rate exceeded a particular value. 
(a) Distribution of Magma Supply (b) Eruption Efficiency

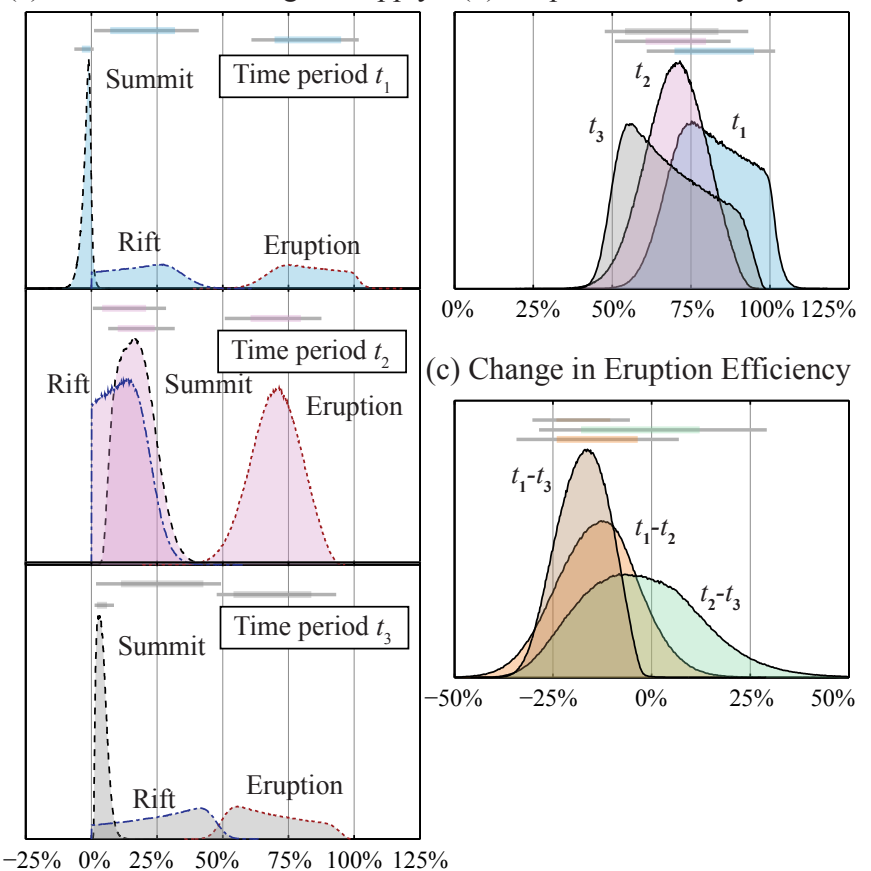

Figure 6: (a) Posterior PDFs (relative probability on vertical axis) showing percentage of MSR by mass entering summit storage, entering the deep rift, and erupted onto the surface for the three examined time periods. For distributions under different assumptions about DRS, see Figure S2. (b) Eruption efficiency. (c) Relative change in eruption efficiency. 